\title{
Springtails (Collembola) in meadows, pastures and road verges in Central Finland
}

\author{
Atte Komonen* \& Saana Kataja-aho
}

\begin{abstract}
Komonen, A. \& Kataja-aho, S. 2017: Springtails (Collembola) in meadows, pastures and road verges in Central Finland. - Entomol. Fennica 28: 157-163.

Understanding of species distribution, abundance and habitat affinities is crucial for red-list assessment, conservation and habitat management. In Central Finland, we studied Collembola in three habitat types, namely non-grazed meadows, pastures and road verges using pitfall traps. Altogether, 9,630 Collembola individuals were recorded. These belonged to 12 families, 34 genera and 60 species. The number of specimens was clearly higher in meadows than in pastures or road verges. The number of species, however, was higher in meadows and road verges (40 and 39 species, respectively) than in pastures ( 33 species). The overall species number is comparable to other large-scale sampling schemes in similar habitats. We recorded a few abundant species (Spatulosminthurus flaviceps, Sminthurus viridis and Sminthurus nigromaculatus) that have been previously recorded from very different biotopes. In conclusion, biodiversity inventories of soil fauna, as well as other biota, should also include marginal habitats, which often host peculiar communities.
\end{abstract}

A. Komonen, University of Jyväskylä, Department of Biological and Environmental Science, P.O. Box 35, FI-40014 University of Jyväskylä, Finland; *Corresponding author's e-mail: atte.komonen@jyu.fi

S. Kataja-aho, University of Jyväskylä, Natural History Museum, P.O. Box 35, FI-40014 University of Jyväskylä, Finland; E-mail: saana.kataja-aho@jyu.fi

Received 15 November 2016, accepted 22 December 2016

\section{Introduction}

Understanding of species distribution, abundance and habitat affinities in different environments is crucial for red-list assessment, conservation and habitat management. Unfortunately, such information is lacking for many invertebrate groups. In Finland, forest soil fauna has been rather wellstudied, partly due to its importance and sensitivity to silviculture (Huhta et al. 1967, 1986, SiiraPietikäinen et al. 2001, Huhta \& Räty 2005, Kataja-aho et al. 2016). At the same time, the knowledge of soil fauna in non-forested habitats is in- sufficient and geographically limited (Pommeresche \& Løes 2014); for example, very little is known about soil fauna in traditional rural biotopes, such as pastures and meadows (Huhta et al. 2010).

Springtails (Collembola) are an important component of soil meso- and macrofauna, because they influence soil decomposition processes (Rusek 1975, Petersen 1994, Hopkin 1997). Springtails can be abundant and diverse even in highly modified and disturbed habitats such as agricultural fields (Lagerlöf \& Andrén 1991, Bitzer et al. 2005, Pommeresche \& Løes 
Table 1. Study site characteristics and total number of individuals and species. Collembola were sampled in 2014 mainly from $26^{\text {th }}-30^{\text {th }}$ of May to $18^{\text {th }}-22^{\text {nd }}$ of June (= first period). If specimens were identified also from the second period $\left(18^{\text {th }}-22^{\text {nd }}\right.$ of June to $7^{\text {th }}-11^{\text {th }}$ of July), the pooled numbers of individuals and species for both periods are given in parentheses. Vegetation height is the average of five study plots.

\begin{tabular}{|c|c|c|c|c|c|c|}
\hline $\begin{array}{l}\text { Habitat } \\
\text { Sites }\end{array}$ & $\begin{array}{c}\text { Area } \\
\text { (ha) }\end{array}$ & $\mathrm{pH}$ & $\begin{array}{c}\text { Soil } \\
\text { fractions }\end{array}$ & $\begin{array}{l}\text { Vegetation } \\
\text { height }(\mathrm{cm})\end{array}$ & Indiv. & Species \\
\hline \multicolumn{7}{|l|}{ Meadows } \\
\hline Peurala & 0.1 & 5.16 & coarse silt & 42 & $128(277)$ & $11(17)$ \\
\hline Kirkonmäki & 0.3 & 4.98 & fine sand & 39 & 103 & 10 \\
\hline Syysniemi & 0.4 & 4.62 & coarse silt & 29 & 380 & 10 \\
\hline Vaaru & 0.4 & 4.33 & medium silt & 33 & 182 & 10 \\
\hline Vuorela & 0.5 & 4.60 & coarse silt & 38 & 369 & 15 \\
\hline Liehu & 0.5 & 4.16 & coarse silt & 36 & 287 & 15 \\
\hline Riihimäki & 0.9 & 4.61 & medium silt & 33 & 485 & 11 \\
\hline Karhukorpi & 1.0 & 4.62 & fine sand & 22 & 1,256 & 15 \\
\hline Vaateri & $1.1^{*}$ & 4.67 & coarse silt & 33 & 309 & 12 \\
\hline Hettee & 2.0 & 4.45 & fine sand & 22 & 256 & 8 \\
\hline Mäentalo & $11.9^{*}$ & 4.93 & fine silt & 39 & $101(136)$ & $7(7)$ \\
\hline Harju & $32.5^{*}$ & 4.39 & medium silt & 24 & 78 & 8 \\
\hline \multicolumn{7}{|l|}{ Pastures with cattle } \\
\hline Pekkanen & 1.7 & 4.27 & fine sand & 30 & 314 & 7 \\
\hline Ohramaa & 5.2 & 4.16 & coarse silt & 30 & 213 & 7 \\
\hline Aatula & 6.1 & 3.73 & medium silt & 15 & 114 & 6 \\
\hline Kivijärvi & 7.6 & 4.70 & coarse silt & 10 & 193 & 9 \\
\hline \multicolumn{7}{|c|}{ Pasture with sheep/cattle } \\
\hline Haapalehto & 8.6 & 4.28 & coarse silt & 14 & 75 (174) & $6(9)$ \\
\hline \multicolumn{7}{|l|}{ Pastures with sheep } \\
\hline Vaateri & $1.1^{*}$ & 5.18 & coarse silt & 39 & 352 & 9 \\
\hline Mäentalo & $11.9^{*}$ & 4.65 & fine silt & 33 & $137(146)$ & $17(17)$ \\
\hline Harju & $32.5^{*}$ & 4.07 & medium silt & 22 & 217 & 7 \\
\hline \multicolumn{7}{|l|}{ Pastures with horses } \\
\hline Koivulahti & 1.1 & 4.24 & fine sand & 15 & 174 & 7 \\
\hline Huusko & 2.6 & 3.96 & coarse silt & 12 & 524 & 13 \\
\hline Nuuttila & 3.1 & 4.70 & coarse silt & 20 & 301 & 13 \\
\hline Suuruspää & 6.0 & 4.98 & fine silt & 21 & 52 & 7 \\
\hline \multicolumn{7}{|l|}{ Road verges } \\
\hline Myllypohja & na & 5.41 & coarse sand & 23 & $39(235)$ & $7(17)$ \\
\hline Multia & na & 5.45 & coarse sand & 8 & 460 & 15 \\
\hline Petäjävesi & na & 5.65 & coarse sand & 10 & 45 & 8 \\
\hline Muurame & na & 5.99 & fine sand & 35 & 13 & 3 \\
\hline Paateri & na & 5.66 & coarse sand & 19 & 5 & 2 \\
\hline Rotkola & na & 4.75 & coarse sand & 20 & 578 & 22 \\
\hline Klemettilä & na & 5.09 & coarse sand & 31 & 49 & 1 \\
\hline Valospohja & na & 4.63 & coarse sand & 27 & 106 & 11 \\
\hline Tammikoski & na & 5.14 & coarse sand & 42 & 21 & 2 \\
\hline Jukola & na & 4.65 & coarse sand & 11 & 553 & 14 \\
\hline Havulankangas & na & 5.22 & coarse sand & 21 & $280(386)$ & $18(20)$ \\
\hline Norola & na & 5.43 & fine sand & 23 & 287 & 12 \\
\hline
\end{tabular}

* Pooled area for meadows and pastures in a given farm.

na: Not applicable.

2014). However, different vegetation types (Huhta et al. 2005) and soil disturbances (Kataja-aho et al. 2016), as well as different levels of soil compaction (Larsen et al. 2004), pollution or nutrient loads (Lagerlöf \& Andrén 1991, Song et al. 2016) can affect composition, structure and small scale spatial heterogeneity of collembolan communities.

Many environmental factors are likely to vary among meadows, pastures and road verges. For 
example, animal tramping affects soil compaction, whereas grazing and excretions affect vegetation and soil chemistry (Oldén 2016). Road salt and traffic pollution can influence biota on road verges (Viard et al. 2004, Owojori et al. 2009). The response of Collembola on environmental variation can vary among euedaphic and epedaphic species; euedaphic species are subsurfaceactive, whereas epedaphic species are surface-active (Eisenbeis \& Wichard 1987).

Traditional rural biotopes have high conservation value, with many rare and threatened plant and invertebrate species. Their soil fauna, however, is much more poorly known. We studied surface-active Collembola in non-grazed meadows, pastures and road verges in Central Finland to better understand biodiversity in these valuable habitats, as well as gain more information about the distribution, abundance and habitat affinity of Collembola.

\section{Materials and methods}

\subsection{Study sites}

This study was conducted in southern and middle boreal vegetation zone in Central Finland. Twelve meadows, pastures and road verges each were selected for the study $\left(n_{\text {tot }}=36\right.$ sites, Table 1). The list of potential meadows and pastures was obtained from the Centre for Economic Development, Transport and the Environment of Central Finland (ELY Centre). All the selected sites were mesic or dry meadows, and had been managed by grazing (pastures) or hand-mowing (meadows) for years. Pastures were a few hectares in size with varying, but generally low intensity, grazing pressure. Meadows had been handmowed once annually, and they had not been treated with animal manure or artificial fertilizers. The most common (occurred in most sites) plant species in meadows and pastures were Veronica chamaedrys, Agrostis capillaris, Alchemilla sp., Festuca rubra, Fragaria vesca, Hypericum maculatum, Poa pratensis, Ranunculus acris, Rumex acetosa and Taraxacum spp.; these were almost equally common in both habitat types.

Road verges were selected as close to the pastures and meadows as possible. All selected roads were tarmacked and belonged to Finnish road category "Local road" or bigger, which ensured at least $3 \mathrm{~m}$ wide verges. The selected roads were all constructed decades ago, there were no signs of recent renovations, and they were outside urban areas. The selected verges were adjacent to a forest, or to a ruderal area in two cases. In Finland, road verges are mowed with machinery 1-2 times yearly; after machine mowing vegetation is generally taller than in hand-mowed pastures. The most common plant species in road verges were Achillea millefolium, Festuca rubra, Taraxacum spp., Epilobium angustifolium, Hieracium umbellatum, Hieracium vulgata group, Trifolium repens, Anthriscus sylvestris, Betula pubescens and Cerastium fontanum.

\subsection{Sampling}

At each pasture and meadow, we established a random $50 \mathrm{~m}$ transect that ran through the center of the site. In road verges, transects ran along the road and at least one meter from the edge of the asphalt. Along transects, five $2 \times 2 \mathrm{~m}$ plots were placed at $10 \mathrm{~m}$ intervals. At two predetermined corners of these plots, we placed one pitfall trap, i.e. there were 10 pitfall traps in each site. All pitfall traps were covered by a plywood roof to exclude rain water; roofs were some $2 \mathrm{~cm}$ from the ground. The pitfall traps were filled with saltwater for preserving the material and soap to reduce surface tension. The pitfall traps were set up $26^{\text {th }}$ $30^{\text {th }}$ of May 2014. They were emptied twice: $18^{\text {th }}$ $22^{\text {nd }}$ of June and $7-11^{\text {th }}$ of July; all traps were catching equal time periods.

Pitfall traps sample surface-active invertebrates (see Gudleifsson \& Bjarnadottir 2008 for a study on Collembola). Due to limited resources, not all Collembola were separated from the pitfall material: from each pitfall at least a hundred different looking specimens were separated for identification and all these were identified to the species if possible. Thus, the data do not warrant statistical comparisons and abundances should be only used to disentangle anecdotal and true habitat affinities. Collembola were identified with, and the nomenclature follows, Fjellberg (1998, 2007). Juvenile collembolans $(n=45)$ were only identified to genus or family. 
Table 2. Numbers of Collembola individuals from pitfall traps from meadows, pastures and road verges recorded during the first period. If specimens were identified from two periods (for periods, see Table 1), the first number indicates the $1^{\text {st }}$ period; pooled numbers of individuals for both periods are given in parentheses.

\begin{tabular}{|c|c|c|c|c|}
\hline Taxa & Meadow & Pasture & Road verge & Total \\
\hline \multicolumn{5}{|l|}{ Arrhopalitidae } \\
\hline Arrhopalites principalis & & 1 & 2 & 3 \\
\hline Arrhopalites sp. & & & 1 & 1 \\
\hline \multicolumn{5}{|l|}{ Bourletiellidae } \\
\hline Bourletiella hortensis & & & 18 & 18 \\
\hline Deuterosminthurus bicinctus & 1 & & & 1 \\
\hline Deuterosminthurus sp. & & & $0(3)$ & $0(3)$ \\
\hline Heterosminthurus claviger & 1 & & 1 & 2 \\
\hline \multicolumn{5}{|l|}{ Dicyrtomidae } \\
\hline Dicyrtoma fusca & $2(14)$ & & $0(1)$ & $2(15)$ \\
\hline Dicyrtomina flavescens & $0(3)$ & & & $0(3)$ \\
\hline Dicyrtoma flavosignata & $3(10)$ & 3 & & $6(13)$ \\
\hline Dicyrtoma minuta & $20(27)$ & 12 & $5(8)$ & $25(47)$ \\
\hline Dicyrtoma ornata & 1 & & 1 & 2 \\
\hline Ptenothrix atra & 25 & & $12(13)$ & $37(38)$ \\
\hline Indet & 2 & 1 & & 3 \\
\hline \multicolumn{5}{|l|}{ Entomobryidae } \\
\hline Entomobrya corticalis & 5 & 1 & $2(4)$ & $8(10)$ \\
\hline Entomobrya marginata & 2 & & $0(4)$ & $2(6)$ \\
\hline Entomobrya multifasciata & & 2 & $1(2)$ & $3(4)$ \\
\hline Entomobrya nicoleti & & 27 & 6 & 33 \\
\hline Entomobrya nivalis & 1 & 7 & 16 & 24 \\
\hline Entomobrya superba & 2 & & & 2 \\
\hline Entomobrya sp. & 1 & $46(49)$ & $4(6)$ & $51(56)$ \\
\hline Heteromurus nitidus & & 27 & & 27 \\
\hline Lepidocyrtus curvicollis & $0(2)$ & & $0(3)$ & $0(5)$ \\
\hline Lepidocyrtus cyaneus & 7 & & 41 & 48 \\
\hline Lepidocyrtus lignorum & $2,378(2,454)$ & $451(468)$ & $959(1,031)$ & $3,788(3,953)$ \\
\hline Lepidocyrtus violaceus & $21(22)$ & 85 & $87(90)$ & $193(197)$ \\
\hline Lepidocyrtus sp. & & 1 & 4 & 5 \\
\hline Orchesella bifasciata & & & 4 & 4 \\
\hline Orchesella cincta & 8 & & & 8 \\
\hline Orchesella flavescens & $30(31)$ & 30 & $45(49)$ & $105(110)$ \\
\hline Orchesella spectabilis & 3 & & & 3 \\
\hline Orchesella sp. & 9 & $15(16)$ & & $24(25)$ \\
\hline Indet & 3 & 5 & & 8 \\
\hline \multicolumn{5}{|l|}{ Hypogastruridae } \\
\hline Ceratophysella sp. & & 57 & $57(61)$ & $114(118)$ \\
\hline Choerutinula inermis & $10(11)$ & 11 & 32 & $53(54)$ \\
\hline Schoettella ununguiculata & 3 & 1 & $20(24)$ & $24(28)$ \\
\hline \multicolumn{5}{|l|}{ Isotomidae } \\
\hline Desoria tolya & $0(1)$ & & $0(11)$ & $0(12)$ \\
\hline Desoria sp. & $6(7)$ & $5(6)$ & $1(17)$ & $12(30)$ \\
\hline Folsomia quadrioculata & 2 & 4 & & 6 \\
\hline Isotoma anglicana & 32 & $402(404)$ & $50(71)$ & $484(507)$ \\
\hline Isotoma caerulea & 58 & 214 & 218 & 490 \\
\hline Isotoma viridis & $121(135)$ & $335(338)$ & $281(322)$ & $737(795)$ \\
\hline Isotoma sp. & $35(36)$ & 21 & $35(39)$ & $91(96)$ \\
\hline Isotomurus graminis & $22(32)$ & 225 & 6 & $253(263)$ \\
\hline Isotomurus italicus & 1 & & & 1 \\
\hline Isotomurus palustris & & 5 & & 5 \\
\hline Isotomurus sp. & 13 & $21(22)$ & 1 & $35(36)$ \\
\hline Parisotoma notabilis & 9 & & 2 & 11 \\
\hline Indet & 107 & 458 & 113 & 678 \\
\hline
\end{tabular}


Table 2, continued

\begin{tabular}{|c|c|c|c|c|}
\hline Taxa & Meadow & Pasture & Road verge & Total \\
\hline \multicolumn{5}{|l|}{ Katiannidae } \\
\hline Gisinianus flammeolus & & 3 & & 3 \\
\hline Sminthurinus aureus & 30 & & 44 & 74 \\
\hline Sminthurinus niger group sp. & 7 & 1 & & 8 \\
\hline Sminthurinus reticulatus & 9 & & 1 & 10 \\
\hline Sminthurinus signatus & 32 & & 1 & 33 \\
\hline Sminthurinus sp. & 5 & 3 & 14 & 22 \\
\hline Indet & 6 & 1 & 1 & 8 \\
\hline \multicolumn{5}{|l|}{ Neanuridae } \\
\hline Friesea mirabilis & & & 4 & 4 \\
\hline Neanura muscorum & 14 & 3 & 9 & 26 \\
\hline Pseudachorutes dubius & & 1 & & 1 \\
\hline Pseudachorutes sp. & 2 & & & 2 \\
\hline Indet & 1 & & & 1 \\
\hline \multicolumn{5}{|l|}{ Onychiuridae } \\
\hline Micraphorura absoloni & & 7 & 1 & 8 \\
\hline Protaphorura armata & & 4 & & 4 \\
\hline Protaphorura sp. & & 1 & & 1 \\
\hline \multicolumn{5}{|l|}{ Poduromorpha } \\
\hline Indet & & 1 & & 1 \\
\hline \multicolumn{5}{|l|}{ Sminthuridae } \\
\hline Allacma fusca & 18 & 5 & $9(14)$ & $32(37)$ \\
\hline Caprainea marginata & & & 1 & 1 \\
\hline Sminthurus nigromaculatus & & & 20 & 20 \\
\hline Sminthurus viridis & $8(11)$ & 7 & $22(26)$ & $37(44)$ \\
\hline Sminthurus sp. & & & 10 & 10 \\
\hline Spatulosminthurus flaviceps & & & 32 & 32 \\
\hline Indet & 2 & 5 & 6 & 13 \\
\hline \multicolumn{5}{|l|}{ Sminthurididae } \\
\hline Sminthurides schoetti & & & 2 & 2 \\
\hline Sminthurides sp. & 4 & & & 4 \\
\hline Sphaeridia pumilis & 38 & 5 & $46(49)$ & $89(92)$ \\
\hline \multicolumn{5}{|l|}{ Symphypleona } \\
\hline Indet & 9 & 14 & 3 & 26 \\
\hline \multicolumn{5}{|l|}{ Tomoceridae } \\
\hline Pogonognathellus flavescens & $798(827)$ & $148(200)$ & $213(270)$ & $1,159(1,297)$ \\
\hline Pogonognathellus longicornis & $11(18)$ & 6 & 5 & $22(29)$ \\
\hline Pogonognathellus sp. & $3(4)$ & $3(5)$ & & $6(9)$ \\
\hline Tomocerus vulgaris & & 1 & & 1 \\
\hline Total & $3,979(4,118)$ & $2,692(2,774)$ & $2,479(2,738)$ & $9,150(9,630)$ \\
\hline
\end{tabular}

Soil samples were taken from each of the five study plots and pooled for one composite sample to measure soil type and $\mathrm{pH}$. Vegetation composition and height $(\mathrm{cm})$ was measured from each of the five study plots $16^{\text {th }}$ June- $8^{\text {th }}$ July 2014 (Table 1).

\section{Results}

Altogether, 9,630 Collembola individuals were recorded. These belonged to 12 families, 34 gen- era and 60 species (Table 2); 12\% (1,164 individuals) of the specimens could not be identified to species. The number of specimens from the first sampling period $(n=9,150)$ was higher in meadows $(n=3,979)$ than in pastures $(n=2,692)$ or road verges $(n=2,479)$. All the results hereinafter concern the first sampling period to allow comparison due to equal sampling period in all sites. The number of species was higher in meadows $(n$ $=40)$ and road verges $(n=39)$ than in pastures $(n$ $=33$ ). There were some differences in soil quality 
and vegetation: soil $\mathrm{pH}$ ranged from 3.73-5.99 and vegetation height 8-42 cm (Table 1). Most $(78 \%)$ of the individuals were Entomobryidae or Isotomidae. The most abundant species were Lepidocyrtus lignorum (41\% of all individuals), Pogonognathellus flavescens (13\%) and Isotoma viridis $(8 \%)$.

\section{Discussion}

The number of collembolan individuals was highest in meadows, whereas pastures and road verges had similarly lower numbers. The number of species was higher in meadows and road verges than in pastures. In all road verges soil fraction was sand, whereas in pastures and meadows soil fractions ranged from sand to fine silt. Although soil type influences collembolan densities (Gudleifsson \& Bjarnadottir 2008), these differences are unlikely to explain the smaller species number in pastures, because the soil type was similar in pastures and meadows. However, the somewhat smaller species number in pastures may result from animals trampling on pitfall traps, which was commonly observed. Animals may also have caused soil compaction, which can decrease the density of collembolans (Heisler \& Kaiser 1995, Larsen et al. 2004).

It is known that collembolan densities in pastures and hayfields are highest in late summer (Gudleifsson \& Bjarnadottir 2008). Even though we did not identify all the specimens and did not sample in late summer, the overall species number is comparable to other large-scale sampling studies in similar habitats with roughly similar number of identified individuals, but different sampling methodology (cf. Huhta et al. 2010).

Most of the recorded individuals were Entomobryidae or Isotomidae. Indeed, epedaphic species are typified by Entomobryoidea and Symphypleona (Hopkin 1997). The most abundant species were Lepidocyrtus lignorum, Pogonognathellus flavescens and Isotoma viridis. These were abundant in all the three habitat types and have been recorded also earlier in great numbers from grasslands (Gudleifsson \& Bjarnadottir 2008). Road verges had more Sminthuridae species than meadows and pastures, but in general there was no species that would clearly favour one habitat type over the others, Spatulosminthurus flaviceps being possibly an exception (see below). Five to eight unique species were recorded from each of the three habitat types, but these were mainly represented by only a few individuals. Although we did not identify all specimens, the similarity of the collembolan fauna among the three habitat types could be a real pattern. The rationale is that the dominant vascular plants were identical among the three habitat types, and vegetation composition and structure are known to affect collembolan densities and diversity (Salamon et al. 2004, Sabais et al. 2011). Overall, the species from pastures, meadows and road verges were rather different from those that are typically caught by pitfalls from forests and clearcuts. The latter usually include Entomobryidae, especially the large species, such as $\mathrm{Po}_{\mathrm{O}}$ gonognathellus and Orchesella (Kataja-aho et al. 2016).

We recorded $S$. flaviceps $(\mathrm{n}=32$ individuals) from several road verges. Previously the species has been found only from salt meadows (Fjellberg 1998). If $S$. flaviceps really is a species that benefits from salt, then the spillover of the de-icing salt on road verges may create a suitable habitat for the species in Finland, far away from coastal areas. More generally, the importance of road verges for salt-favouring species deserves further attention.

In addition, Sminthurus viridis and S. nigromaculatus were recorded in great numbers, the former from all studied biotopes and the latter only from road verges. Although the occurrence of these species in Finland was uncertain according to Fjellberg (1998), later both of these species have been discovered from Finland (P. Vilkamaa, pers. comm.). In conclusion, our study corroborates the results by Huhta et al. (2010) in that many non-forested habitats host a peculiar Collembola fauna. Systematic studies in marginal or otherwise poorly studied biotopes are crucial to get a thorough understanding of species abundance, distribution and habitat affinities.

Acknowledgements. We thank two anonymous reviewers for their suggestions to improve the manuscript and Koneen Säätiö for funding the project "Perinneympäristöjen ja niitä korvaavien kulttuuriympäristöjen hoito biologisen monimuotoisuuden, sosiaalisen kestävyyden ja taloudellisen tehokkuuden näkökulmasta". 


\section{References}

Eisenbeis, G. \& Wichard, W. 1987: Atlas on the biology of soil arthropods. - Springer, Berlin, Germany. 437 pp.

Fjellberg, A. 1998: The Collembola of Fennoscandia and Denmark. Part I: Poduromorpha. — Fauna Entomologica Scandinavica 35: 1-184. Brill, Leiden.

Fjellberg, A. 2007: The Collembola of Fennoscandia and Denmark. Part II: Entomobryomorpha and Symphypleona. - Fauna Entomologica Scandinavica 42: 1264. Brill, Leiden.

Gudleifsson, B. E. \& Bjarnadottir, B. 2008: Springtail (Collembola) populations in hayfields and pastures in northern Iceland. - Icelandic Agricultural Sciences 21: 49-59.

Heisler, C. \& Kaiser, E. A. 1995: Influence of agricultural traffic and crop management on collembolan and microbial biomass in arable soil. — Biology and Fertility of Soils 19: 159-165.

Hopkin, S. P. 1997: Biology of the Springtails (Insecta: Collembola). — Oxford University Press, New York, U.S. 330 pp.

Huhta, V., Karppinen, E., Nurminen, M. \& Valpas, A. 1967: Effects of silvicultural practices upon arthropod, annelid and nematode populations of coniferous forest soil. — Annales Zoologici Fennici 4: 87-143.

Huhta, V., Hyvönen, R., Kaasalainen, P., Koskenniemi, A., Muona, J., Mäkelä, I., Sulander, M. \& Vilkamaa, P. 1986: Soil fauna of Finnish coniferous forests. - Acta Zoologica Fennica 23: 345-60.

Huhta, V. \& Räty, M. 2005: Soil animal communities of planted birch stands in Central Finland. - Silva Fennica 39: 5-19.

Huhta, V., Räty, M., Ahlroth, P., Hänninen, S.-M., Mattila, J., Penttinen, R. \& Rintala, T. 2005: Soil fauna of deciduous forests as compared with spruce forests in central Finland. - Memoranda Societatis pro Fauna et Flora Fennica 81: 52-70.

Huhta, V., Siira-Pietikäinen, A., Penttinen, R. \& Räty, M. 2010: Soil fauna of Finland: Acarina, Collembola and Enchytraeidae. - Memoranda Societatis pro Fauna et Flora Fennica 86: 59-82.

Kataja-aho, S., Hannonen, P., Liukkonen, T., Rosten, H., Koivula, M. J., Koponen, S. \& Haimi, J. 2016: The arthropod community of boreal Norway spruce forests responds variably to stump harvesting. - Forest Ecology and Management 371: 75-83.
Lagerlöf, J. \& Andrén, O. 1991: Abundance and activity of Collembola, Protura and Diplura (Insecta, Apterygota) in four cropping systems. - Pedobiologia 35: 337 350 .

Larsen, T., Schjonning, P. \& Axelsen, J. 2004: The impact of soil compaction on euedaphic Collembola. Applied Soil Ecology 26: 273-281.

Oldén, A. 2016: Plant biodiversity in boreal wood-pastures - impacts of grazing and abandonment. - PhD Thesis, Jyväskylä studies in biological and environmental science 318. Jyväskylä. 46 pp.

Owojori, O. J., Reinecke, A. J., Voua-Otomo, P. \& Reinecke, S. A. 2009: Comparative study of the effects of salinity on life-cycle parameters of four soil-dwelling species (Folsomia candida, Enchytraeus doerjesi, Eisenia fetida and Aporrectodea caliginosa). - Pedobiologia 52: 351-360.

Petersen, H. 1994: A review of collembolan ecology in ecosystem context. - Acta Zoologica Fennica 195: 111-118

Pommeresche, R. \& Løes, A.-K. 2014: Diversity and density of springtails (Collembola) in a grass-clover ley in North-west Norway. - Norwegian Journal of Entomology 61: 165-179.

Rusek, J. 1975: Die bodenbildende Funktion von Collembolen und Acarina. — Pedobiologia 15: 299-308.

Sabais, A. C. W., Scheu, S. \& Eisenhauer, N. 2011: Plant species richness drives the density and diversity of Collembola in temperate grassland. - Acta Oecologica 37: 195-202.

Salamon, J.-A., Schaefer, M., Alphei, J., Schmid, B. \& Scheu, S. 2004: Effect of plant diversity on Collembola in experimental grassland ecosystem. - Oikos 106: 51-60.

Siira-Pietikäinen, A., Pietikäinen, J., Fritze, H. \& Haimi, J. 2001: Short-term responses of soil decomposer communities to forest management: clear felling versus alternative forest harvesting methods. - Canadian Journal of Forest Research 31: 88-99.

Song, L., Liu, J., Yan, X., Chang, L. \& Wu, D. 2016: Euedaphic and hemiedaphic Collembola suffer larger damages than epedaphic species to nitrogen input. Environmental Pollution 208: 413-5.

Viard, B., Pihan, F., Promeyrat, S. \& Pihan, J.-C. 2004: Integrated assessment of heavy metal $(\mathrm{Pb}, \mathrm{Zn}, \mathrm{Cd})$ highway pollution: bioaccumulation in soil, Graminaceae and land snails. — Chemosphere 55: 1349-1359. 